\title{
SOCIAL MEDIA, ELECTIONS AND POLITICAL ENGAGEMENT: The 2014 General Election in Mauritius
}

\section{Roukaya Kasenally and Dooshweena Awatar}

\author{
Roukaya Kasenally is a senior adviser at the African Media Initiative (AMI) \\ and a senior lecturer in media and political systems at the \\ University of Mauritius \\ email: roukaya@uom.ac.mu
}

Dooshweena Awatar is a Research Assistant working on politics in Mauritius email: dooshweena.awatar@gmail.com

\begin{abstract}
Mauritius has preferred the ballot to the bullet, earning its status as a democracy to be emulated within Africa. Elections are a regular feature of the Mauritian political landscape, and since it became independent in 1968 the small island has already held ten elections deemed to be free and fair. Another notable feature is the relatively high level of voter turnout, which has hovered at between $70 \%$ and $85 \%$ for the past ten general elections. With such an impressive scoreboard all should be fine, but unfortunately this is not the case. Over the past few years a number of gnawing democratic deficits have been noted, in particular the advent of dynastic politics, the rise of ethnopolitics and the presence of big money in politics. Elections have seen the alternation of power but unfortunately it has been with the same parties and the same leaders. In fact, across the world established politics is in crisis and Mauritius is not exempt from this state of affairs. The objective of this paper is to explore the possibility of doing politics differently through the use of new technology and social media. The paper will explore whether Mauritius has followed the trend of what is now being termed direct democracy, and the possibility for a new kind of political engagement and in the process the construction of a new political discourse.
\end{abstract}

Keywords: social media, elections, democratic consolidation, political engagement and political renewal 


\section{INTRODUCTION}

There is a growing body of literature on the role and impact that new and social media are having on elections. This seems to be even more visible in countries where traditional media are either under the control of the state (national television) or severely restricted in their capacity to be independent and autonomous (private media). In a recently released publication, Schiffrin (2017) speaks about media capture by both the state and business interests.

Over the last decade there has been an accelerated use of new media, which has ushered in the phenomenon of social media through the popularisation of platforms such as Facebook, Twitter, Snapchat, Instagram and You Tube. The study of media effects has a clear evolution from the hapless and a helpless audience (Lasswell 1927; Lippmann 1922) to the limited effects theory (Klapper 1960; Lazarsfeld, Berelson, \& Gaudet 1944). The effects theory was subsequently inversed from: what does the media do to people, to what do people do with the media - the uses and gratifications theory (Blumler \& Katz 1974). Studies on the effect of new media and particularly digital technologies are only just beginning to emerge (Bryant \& Thompson 2002). Media consumers are no longer called simply an audience but are now users and producers, heralding a new era of active consumption and distribution. This is in turn creating an ecosystem where new relationships and meanings are emanating from the confluence between media, politics and the audience.

Politics and the media have always had a keen interest in each other and represent two pillars through which ideological influence and control are exercised (Herman \& Chomsky 1988). Patterns of ownership have become more defined by power than by public service and/or profit (Schiffrin 2017). Elections are often considered an important test case between media and politics, between media capture and media independence.

This article will explore the case of Mauritius, a country that has espoused the ballot and not the bullet culture (Bunwaree \& Kasenally 2005), where elections have been classified as free and fair by international observers, where voter turnout ranks high and where the media is often celebrated for its diversity.

The case of the 2014 general election will be analysed as the latter was the first election in Mauritius in which social media was used as a means of political engagement by political parties. What type of political messages were generated, the quality of the political discourse and the response from the citizen/user will be analysed. The post-2014 general election period will also be studied to consider whether the type and nature of political engagement has evolved, and if so for what purpose. 


\section{SETTING THE SCENE: MEDIA AND DEMOCRACY IN MAURITIUS}

As mentioned earlier, Mauritius has nurtured a tradition of holding regular elections every five years. It tops the democratic league in Africa as a 'full democracy' (EIU Report 2016), one where political rights and civil liberties attain a combined score of 1.5 (Freedom House 2016) and where the media is considered to be relatively free.

Politics and the media have an important historical link in Mauritius. In fact, the written media in Mauritius spans some 250 years and is one of the most established institutions in the southern hemisphere. The media, and especially the written media, played a significant role in the political emancipation of the Indo-Mauritians. As early as 1832 when the island was under French rule the first newspaper appeared. Le Cerneen was essentially used to safeguard the interests of the Franco-Mauritian elites and those closely associated with them. The visit of Mahatma Gandhi in 1901 would be a turning point for Indo-Mauritians, who were strongly urged to educate themselves and become politically mobilised. A number of Hindi and other oriental language newspapers would subsequently appear and were used as an important tool for political advocacy among the Indo-Mauritians.

The battle for independence was to a large extent fought in the columns of the newspapers. A number of pro-independence titles appeared, such as L'Express which would give the emerging middle class a greater role in the running of the country. This was achieved to a limited extent in 1947 through the formalisation of a new Constitution that increased the number of eligible voters from 11000 to 72000 and in the process modestly increased the political clout of the IndoMauritians. The extension of the franchise was advocated by a relatively young party, the Mauritius Labour Party (MLP), which had a sympathetic hearing in the pro-independence newspapers. As Mauritius headed towards independence and ultimately became independent in 1968 there was a clear split in the population, with $44 \%$ voting against independence. This was mirrored in the different newspapers that supported either pro- or anti-independence movements. It is thus interesting to note the role that an important section of the written press played in the political awakening and ultimate emancipation of the Mauritian citizenry. Another point worth reflecting on was the capacity of the written media to campaign for a common cause, that is the independence of Mauritius.

\section{Post-Independence: The Media, Friend or Foe?}

The post-independence period is important in the life of any new nation. This was especially so for Mauritius as the country was fragmented following the split views 
on independence. Under the leadership of Sir Seewoosagur Ramgoolam (SSR) immediately after independence, this was seen as an opportunity to federate the divided nation and appeal to a sense of unity. In fact, he was commended for his ability to steer the small island 'from a potentially explosive racial hothouse into a bustling, prosperous, politically hectic sustainable democracy' (Rotberg 2003). The immediate post-independence period saw the written press (especially those that had a direct hand in the pro-independence movement) deliberately distance itself from the ruling party, with the aim of creating a free and independent media (Paroomal 2008).

The euphoria of this post-independence time was relatively short-lived with the advent of a young political party that grew from the May 1968 student protests and espoused Marxist ideology - the Mouvement Militant Mauricien (MMM). Matters were further aggravated with the postponement of the first post-independence general election due in 1972. In 1971, SSR promulgated the Public Order Act (this has subsequently been replaced by the Public Gathering Act of 1991) aimed at clamping down on political and media freedoms. This period lasted until December 1976 when the long-expected general election was held. The written media suffered tremendous censorship as it was branded proopposition by the ruling party. Ironically, the very press that had been supportive of the independence movement were viewed as troublemakers just six years after independence. This at times oppositional not to say antagonistic approach would repeat itself a couple of times, in 1984 with the Newspapers and Periodicals Bill ${ }^{1}$ and again in the mid-2000s, with the repeated threat from government to regulate the press through some form of statutory regulation.

Table 1 below lists some of the current legislation governing the media in Mauritius. Unlike the written media (which has no regulatory body or specific law), broadcast media falls under the MBC Act (1982) and the IBA Act (2000). It is, however, important to note that within the Mauritian Criminal Code issues pertaining to sedition, defamation and publishing false news are clearly listed as punishable offences. The Official Secrets Act of 1972, which is part of the island's colonial legacy, also remains in force.

1 This bill required a significant financial guarantee from any editor for setting up and running a newspaper. It was finally abandoned after sustained protest from the media corps. 


\section{Table 1}

\section{Current Legislation Defining the Mauritian Media Landscape}

\begin{tabular}{|c|c|}
\hline $\begin{array}{l}\text { Criminal Code Article } 299 \text { - } \\
\text { Publishing false news }\end{array}$ & $\begin{array}{l}\text { 'where the offence is committed by means of any writ- } \\
\text { ing, newspaper, pamphlet or printed matter or by any } \\
\text { means other than spoken words, by a fine which shall } \\
\text { not be less than } 20,000 \text { rupees and not more than } \\
50,000 \text { rupees and imprisonment for a term not exceed- } \\
\text { ing one year' }\end{array}$ \\
\hline $\begin{array}{l}\text { Criminal Code } \\
\text { Article } 288 \text {-Interpretation of } \\
\text { defamation }\end{array}$ & $\begin{array}{l}\text { Any person who, by any of the means specified in sec- } \\
\text { tion } 206 \text { (by any writing, newspaper, pamphlet or other print- } \\
\text { ed matter, or by any drawing, engraving, picture, emblem or } \\
\text { image, sold or distributed or put up for sale or exhibited in } \\
\text { any public place or meeting), is guilty of defamation shall } \\
\text { be liable to imprisonment for a term not exceeding one } \\
\text { year and a fine not exceeding } 5,000 \text { rupees. }\end{array}$ \\
\hline $\begin{array}{l}\text { Article 202: Publishing mat- } \\
\text { ter without description of } \\
\text { author }\end{array}$ & $\begin{array}{l}\text {... liable to a fine not exceeding } 10,000 \text { rupees and to } \\
\text { imprisonment for a term not exceeding } 6 \text { months. ... any } \\
\text { copies seized shall be forfeited. }\end{array}$ \\
\hline $\begin{array}{l}\text { Article 282: Stirring up racial } \\
\text { hatred }\end{array}$ & $\begin{array}{l}\text { For the author of hate speech, } \ldots, \text { liable to a fine not } \\
\text { exceeding } 25,000 \text { rupees and penal servitude for a term } \\
\text { not exceeding ten years. For publisher ... liable to a fine } \\
\text { not exceeding } 25,000 \text { rupees and to imprisonment for a } \\
\text { term not exceeding two years }\end{array}$ \\
\hline
\end{tabular}




\begin{tabular}{|c|c|}
\hline Article 283 : Sedition & $\begin{array}{l}\text { be liable to imprisonment for a term not exceeding one } \\
\text { year and a fine not exceeding 20,000 rupees }\end{array}$ \\
\hline $\begin{array}{l}\text { Article } 284 \text { Inciting to dis- } \\
\text { obedience or resistance to } \\
\text { law }\end{array}$ & $\begin{array}{l}\text { liable to imprisonment for a term not exceeding one } \\
\text { year, and a fine not exceeding 2,000 rupees. }\end{array}$ \\
\hline $\begin{array}{l}\text { Art. } 287 \text { Suspending publica- } \\
\text { tion of newspaper containing } \\
\text { seditious publication }\end{array}$ & $\begin{array}{l}\text { liable to a fine not exceeding } 10,000 \text { rupees and to im- } \\
\text { prisonment for a term not exceeding one year. }\end{array}$ \\
\hline Article 296 Insult & $\begin{array}{l}\text { where the offence is committed by means of any written } \\
\text { or printed matter, drawing, picture, emblem or image, } \\
\text { imprisonment for a term not exceeding three months } \\
\text { and a fine not exceeding 10,000 rupees }\end{array}$ \\
\hline $\begin{array}{l}\text { National Assembly (Privileg- } \\
\text { es, Immunities and Powers) } \\
\text { Act }\end{array}$ & $\begin{array}{l}\text { Section 6: Contempt of National Assembly. Subsection } \\
\text { (1) (n) publishing any defamatory statement or writ- } \\
\text { ing upon the Assembly or any committee, or upon any } \\
\text { member touching, or relating to, his character or conduct } \\
\text { as a member and with regards to actions performed or } \\
\text { words uttered by him in the Assembly. }\end{array}$ \\
\hline $\begin{array}{l}\text { Independent Broadcasting } \\
\text { Authority (IBA) Act of } 2000\end{array}$ & $\begin{array}{l}\text { Revocation and suspension of licence } \\
\text { Any person who commits an offence shall, on convic- } \\
\text { tion, be liable to a fine not exceeding 100,000 rupees and } \\
\text { to imprisonment for a term not exceeding two years }\end{array}$ \\
\hline $\begin{array}{l}\text { The Mauritius Broadcasting } \\
\text { Corporation Act of } 1982\end{array}$ & $\begin{array}{l}\text { Any person who contravenes this Act or any regulations } \\
\text { made under it shall commit an offence and shall, on con- } \\
\text { viction, be liable to a fine not exceeding } 2,000 \text { rupees and } \\
\text { to imprisonment for a term not exceeding two years }\end{array}$ \\
\hline
\end{tabular}




\begin{tabular}{|l|l|}
\hline Official Secrets Act of 1972 & $\begin{array}{l}\text { liable to imprisonment for a term not exceeding } 12 \\
\text { months / liable to imprisonment for a term of not less } \\
\text { than one month and not more than } 12 \text { months together } \\
\text { with a fine not exceeding 2,000 rupees, / liable to penal } \\
\text { servitude for a term not exceeding 15 years (depending } \\
\text { on offence) }\end{array}$ \\
\hline
\end{tabular}

Source: Compiled from Mauritian Laws

\section{MEDIA DIVERSITY AND THE DEMOCRATISATION OF INFORMATION}

A number of media tracking institutions (see FES Media Africa, Freedom House and IREX) commend Mauritius for the diversity of its media titles. Despite the presence of defamation and libel within the Mauritian Criminal Code most journalists are relatively free to report on a range of issues. Elections are important moments in the lives of all citizens and Mauritians are no different. Written media has had a presence of over 250 years on the island, whereas broadcast media (television and radio) is relatively new. Public, not to say state media has been available since the mid-1960s and private commercial radio stations since 2002. Unfortunately no private television station exists on the island, although there are a number of web TVs that have started up in the last three years. For many the advent of private commercial radio stations has been a key factor in the democratisation of information and radio (as in many parts of the world) remains one of the most accessible and popular forms of communication. The use of Creole rather than French as the main language of communication ensures that its outreach has more impact. The different radio programmes on offer are formatted to privilege audience phone-ins and other chat shows that deal with the different social, economic and political issues present on the island.

As mentioned earlier, Mauritians have a particular appetite for politics which constitutes a regular feature of news, analysis and commentary in both written and broadcast media. However, the democratisation of access to information and communication space has not always ensured the quality of political commentary and debate - the ever-present dilemma of quality versus quantity. We shall come back to the issue of political commentary when we discuss the nature and tone of the political conversation(s) that characterised the 2014 general election.

Table 2 outlines the evolution of the communication/media landscape in relation to the ten general elections held in Mauritius after independence. 
Table 2

Post-Independence General Elections and Media Landscape

\begin{tabular}{|c|c|}
\hline $\begin{array}{l}\text { General } \\
\text { Election }\end{array}$ & Means of Media / Communication \\
\hline 1976 & $\begin{array}{l}\text { Post Public Order Act (1971), written media, state television and radio } \\
\text { The first time that the MMM fielded candidates for an election } \\
\text { The only time that elections would be contested as a three-corner fight; sub- } \\
\text { sequently all elections would be contested as a pre-election coalition }\end{array}$ \\
\hline 1982 & $\begin{array}{l}\text { Written media, state television and radio } \\
\text { Abuse of state media by incumbent } \\
\text { The first } 60-0 \text {, where the opposition party won all seats }\end{array}$ \\
\hline 1983 & $\begin{array}{l}\text { Written media, state television and radio } \\
\text { Abuse of state media by incumbent } \\
\text { The newly created MSM (following the fragmentation of the MMM) contests } \\
\text { the election for the first time in coalition with the MPL and PMSD }\end{array}$ \\
\hline 1987 & $\begin{array}{l}\text { In } 1984 \text { an attempt to pass the Newspapers and Periodical Bill was resisted } \\
\text { by media professionals } \\
\text { Written media, state television and radio } \\
\text { Abuse of state media by incumbent }\end{array}$ \\
\hline 1991 & $\begin{array}{l}\text { Written media, state television and radio } \\
\text { Abuse of state media by incumbent }\end{array}$ \\
\hline 1995 & $\begin{array}{l}\text { Mauritius is now a republic following the amendment to the Constitution } \\
\text { in } 1991 \\
\text { Written media, state television and radio } \\
\text { Abuse of state media by incumbent } \\
\text { The second } 60-0 \text { result, where the opposition party wins all } 60 \text { seats }\end{array}$ \\
\hline 2000 & $\begin{array}{l}\text { Written media, state television and radio } \\
\text { Abuse of state media by incumbent }\end{array}$ \\
\hline 2005 & $\begin{array}{l}\text { The IBA Act (2000) provides for the setting up of private commercial radio } \\
\text { stations } \\
\text { Three private commercial radios stations have been in operation since } 2002 \\
\text { Written media, state television and radio } \\
\text { Abuse of state media by incumbent }\end{array}$ \\
\hline 2010 & $\begin{array}{l}\text { Written media, private commercial radios and state media and radio } \\
\text { Abuse of state media by incumbent }\end{array}$ \\
\hline 2014 & $\begin{array}{l}\text { New and social media } \\
\text { Written media, Web TV, private commercial radios and state media and radio } \\
\text { Abuse of state media by incumbent }\end{array}$ \\
\hline
\end{tabular}


Table 2 offers an overview of how the post-independence general elections have been influenced by the evolving media landscape. The systematic abuse of the national broadcaster (the MBC) by incumbents, which intensified during election campaigns, has been regularly documented by domestic observers as well as International Observation Missions (see EISA Election Observation Report 2010 and AU Election Observation Report 2014). Despite its often biased treatment and coverage of political news, the $\mathrm{MBC}$, as the national/state broadcaster, is required to provide airtime to all registered political parties as part of the Political Electoral Broadcast (PEB) during each electoral campaign. Airtime is based on two criteria, namely the number of seats held in the outgoing parliament and the number of candidates fielded (Kasenally 2009). Private commercial radio stations had been operating for nearly eight years, and by 2010 their presence and impact were tangible. This prompted the IBA to produce a 'Political Broadcasts and Party Election Broadcasts General Guidelines for Private and Public Broadcasters: General Elections 2010', prefaced with the instruction: 'Broadcasting licensees shall ensure that these Guidelines are strictly adhered to by their employees and agents, and, wherever applicable, their interviewees'.

\section{ELECTORAL CAMPAIGNS, NEW AND SOCIAL MEDIA: FORCE FOR CHANGE OR A MERE FLASH IN THE PAN?}

International events in the past decade bear witness to the rise of social media. The Iranian protest against the re-election of Mahmoud Ahmadinejad in 2009, the Red Shirt uprising in Thailand in 2010 (Shirky 2010), the Arab Spring in early 2011 (Carlisle \& Patton 2013), the 'Y'en a Marre' youth protestation in Senegal (2011) and the 'Umbrella Movement' in Hong Kong (2014) are all testimony that social media has not only changed ordinary citizens' lives but is also the main force behind the drive to change the political affairs of a particular country. Social media does not only impact the lives of people in authoritarian regimes, it is now being used as a major tool in political communication in democracies. This has been made possible due to the 'free public space of the internet' (Castells 2013).

Barack Obama's electoral campaign for the United States (US) presidential election in 2008 is where this seems to have started. Parallels were even drawn between President Barack Obama's innovative use of the Internet in 2008 and President John F. Kennedy's pioneering use of television in the 1960 US presidential race (Aronson 2011). Facebook was used intensively for the first time 'to obtain campaign information and/or share campaign news with others, exchange their political views and express support for a candidate' (Kushin \& Yamamoto 2010). By using interactive Web 2.0 tools, Obama's campaign changed the way politicians organise supporters, advertise to voters, communicate with them, and defend 
themselves against criticism (Miller 2008). Obama, as the presidential candidate, was very active on social media platforms, gathering around five million supporters online. By November 2008, Obama had nearly 2.4 million Facebook supporters, compared to his opponent, John McCain's 640000. On Twitter, Obama had over 11000 followers and McCain had fewer than 5000 (Hwang 2016).

The recent 2016 U.S election once again highlighted the role of social media during electoral campaigns in America. Donald Trump's substantial social media usage, coupled with his pompous personality, helped keep him in the limelight (Hwang 2016). Bernie Sanders' digital campaign is also fascinating because it was mostly driven by his supporters. The hashtag campaign \#FeelTheBern was created by Sanders' Twitter followers and was extensively used to promote his policies, and to demonstrate and amass support for him.

As the use of smartphones rose globally, that of social media also increased. It is thus especially interesting to look at the impact of social media in non-Western countries where access to smartphones and the Internet has gradually become easier. Three countries stand out as interesting: India (with a population of over 1 billion and often called the world's biggest democracy), Nigeria (Africa's most populous country and riddled with corruption) and Ghana (one of Africa's most stable democracies). These three countries offer significant insights into the use and impact of new and social media during their most recent elections.

\section{India's 2.0 Elections: The Digital Era}

The Indian general election of 2014 was the longest campaign in the country's history, with the highest recorded voter turnout (Schedule of Elections 2014). This election was also unique because of the way social media was used to reach out to voters (Biswas et al. 2014). Price (2015) speaks about the arsenal of modern technologies used by Modi to make his campaign disruptive and innovative.

The Bharatiya Janata Party (BJP), which became the first party since 1984 to win an absolute majority in India's parliament, engaged citizen supporters in the party's successful social media campaign (Chadha \& Guha 2016). The team of prime ministerial candidate Narendra Modi used an aggressive social media strategy while campaigning, tweeting and updating Facebook users multiple times per day. By the time he was sworn in as Prime Minister, Modi had more than 16 million 'likes' on his Facebook page, the second most for any politician in the world, and he was the sixth most-followed world leader on Twitter (Ali 2014). YouTube videos, translated into several local languages, were also uploaded regularly with Modi emphasising key issues that concerned the population (Chadha \& Guha 2016).

Digital media itself was used unconventionally by the BJP for campaigning purposes during the 2014 Indian election. The BJP, along with the Citizens for 
Accountable Governance, organised an innovative campaign called 'Chai Pe Charcha' (Hindi phrase for discussion over tea). This enabled Modi, as the prime ministerial candidate, to interact with people at tea stalls in predetermined places using a combination of satellite, DTH, internet and mobile. The programme was relayed to 1,000 tea stalls in 300 cities across the country (Ali 2014, Price 2015). There were also virtual rallies where Modi simultaneously addressed large numbers of voters in 3D using hologram technology. This helped him reach parts of India where he was unknown (Price 2015).

\section{Nigeria's 2014 Electoral Campaign}

The election of Muhammadu Buhari as President of Nigeria has been hailed internationally as a historic transfer of power for Africa's most populous nation. It was the first in which a sitting president was defeated (Eddings 2015). At a time when the incumbent president was seen as the enemy of democracy for having suppressed the free circulation of newspapers (Olowojolu 2016), social media came to the fore as the driving force of Buhari's campaign between March and April 2015. The change message of Buhari's party, the All Progressives Congress' (APC), was compelling and captivated Nigerians throughout the campaign (Egbunike 2015).

Social media was used by candidates and their parties to disseminate information and to solicit support and sympathy from the population (Aduloju 2016). Hashtags of trending events were created on Facebook and Twitter for easy access to news and information (Aduloju 2016). News agencies, civil society and the Independent National Electoral Commission (INEC), for example, made use of the hashtag \#NigeriaDecides to categorise and share information pertaining to the election (Aduloju 2016). INEC also used the opportunity to develop its communication channels and engage with citizens through Facebook, YouTube and Twitter. Its situation room was established with the aim of enabling people to contact the organisation directly to report misconduct and concerns about the poll (Bartlett et al. 2015).

Over the period of 18 March-22 April 2015, researchers collected 13.6 million tweets posted by 1.38 million unique users associated with the Nigerian Presidential and State elections. Data (posts and interactions) was also collected from 29 election relevant public pages on Facebook (Bartlett et al. 2015). Twitter was found to be ten times more active over the election period than at 'normal' times; 12.4 million tweets were generated about the elections over that period (Bartlett et al. 2015).

Sunday Dare, chief of staff and media adviser to the head of Buhari's political party, best summarised the role of social media during the electoral campaign: 
I think this election was decided, dominated and directed by social media. The power of social media came out for this country. Social media played a central role as a watchdog in keeping the integrity of the process. Within minutes of votes being counted at a polling unit, the results were all over social media. Ordinary people with Excel sheets were doing tallies. At the end of the day when it was announced officially, the results matched. So social media were central because of the immediacy, because it was in the hands of so many citizens who were involved, who were interested. In a way, social media seized the day from the legacy media. You had almost everyone depending on social media for the breaking news. Social media came alive for us this time.

Dare 2015

\section{\#GhanaDecides}

Ghana's 2016 election was considered to be one of the most fascinating elections in its history, as it was the first time that the incumbent president had failed to win a second term (Opara 2017), leading to the win of Nana Akufo-Addo.

Realising the effectiveness of the Nigerian social media electoral campaigns, Nana Akufo-Addo and his team hired the same group that had elected Nigeria's President Muhammadu Buhari and the APC into power with their aggressive use of social media (Opara 2017). 'Change' banners flooded social media. With the hashtags \#Knowyourpresident, and \#ChangeIsComing, his campaign strategists portrayed him in a way that appealed to everyone (Opara 2017). The team of the incumbent, John Mahama, also made full use of social media as a campaign tool. They regularly uploaded drone-filmed videos to show the infrastructural works being done across the country; John Mahama himself personally tweeted and engaged with his followers throughout the campaign (Opara 2017). Social media was also used by the Electoral Commission as a means to deliver an effective voter education campaign with a pertinent video education series on the voting and electoral processes, regularly sharing updates on its Twitter and Facebook (Penplusbytes 2017).

What is indeed undeniably striking about Ghana's 2016 election is the way social media has been widely used to ensure a safe and democratic electoral process. Penplusbytes, a non-governmental organisation committed to using new technologies to strengthen governance, developed several platforms to safeguard the holding of a free and fair election. By using software programmed with keywords to track what Ghanaians were posting online during the polling, the organisation wanted to record some of the key issues on the streets (Hairsine, 2016). 
The team could then use such data to detect potential irregularities or violence and pass these incidents on to the appropriate authorities (Hairsine 2016).

\section{The Youth Dividend}

All of the electoral campaigns referred to above took place at crucial times where there was an accelerated use of the Internet and smartphones. Social media had already been present during past elections, but it had been used sparingly. Another feature seems to connect these three countries, that is the presence of a sizeable youth segment.

Social media can be a game-changing feature in the political landscape because it has the ability to increase political participation among young voters not typically involved in politics (Aronson 2012). The popularity of social media sites like YouTube, Facebook and Twitter, especially among the younger generation, provides a highly visible environment for candidates to promote themselves and interact with voters (Vitak et al. 2009). In his 2008 campaign, Obama understood the potential success of social media strategies with the youth. This is why he specifically hired 'Facebook co-founder Chris Hughes to revolutionize his new media campaign and provide expertise of the various social networking platforms that resonated with the millennial generation that had always been technologically connected' (Stelter 2008, p.6).

In India, according to the Election Commission, there was an increase of 100 million voters for the 2014 general election, compared to the previous general election in 2009. Urban India had 78 million social media users in June 2013 and this number rose to 91 million by December 2013, according to the Internet \& Mobile Association of India's report (IAMAI Annual Report 2015). Indian voters were likely to access the Internet with ease, but social media use levels were especially high among the millions of citizens between the ages of 18 and 23 who became eligible to vote for the first time (Singh 2016). The BJP thus understood the need to reach out to first-time voters who represented a sizeable segment of the youth population.

'We saw a trend, we read this trend, where the youth of the country were embracing social media as their first tool when they started using the internet, and we made sure our presence was there', said Arvind Gupta, who as head of BJP's IT division led the party's social media campaign (Ali 2014). Modi himself reached out through Twitter to the young, appealing to what the youth were looking for: jobs, security and the use of technology.

In Ghana, around 7.9 million people had access to the Internet and 3.5 million Ghanaians, out of a population of 28 million, were active on Facebook in 2016 (internetworldstats.com); $34 \%$ of the Facebook users in Ghana were between the 
ages of 25 and 35, with $41 \%$ between 18 to 24 years of age (Penplusbytes Report 2016). Both parties, understanding that their audiences were mainly the youth, emphasised messages targeted at this demographic. For example, incumbent President Mahama encouraged young citizens to vote and not to resort to violence on polling day. Through social media Akufo-Addo invited youngsters to campaign rallies, and also asked them to think about their country's future before casting their votes.

In Nigeria, $51 \%$ of the population was using the Internet around election time (Barlett et al. 2015). 'Most individuals also own a personal mobile phone $(83 \%)$ with half of those who do not reporting that they have access to a mobile phone owned by someone else (55.1\%)' (Udoka 2015). 'Home Internet access also increased sharply [...] 95.7\% of weekly Internet users say they accessed the Web using a mobile device in the past week.' (Udoka 2015). With these figures, it is certain that social media played a crucial role during the election period and led to a high level of political participation from the young demographic. This is also confirmed by personal mobile ownership rates across age groups being the highest among those aged 25 to 34 (89.3\%) (Udoka 2015). Developing a social media strategy specifically for election campaigning was thus deemed as an intelligent move. Both front running parties used 'Google Hangouts', in which candidates could answer the questions of young Nigerians (Barlett et al. 2015).

\section{THE 2014 MAURITIAN GENERAL ELECTION: HARNESSING THE DIGITAL FOOTPRINT}

The 2014 general election came a year ahead of its scheduled time, precipitated by a pre-coalition deal between the MLP and MMM. Predicted as a clear victory by its two leaders, Navin Ramgoolam and Paul Berenger respectively, it saw the win of the cobbled coalition led by the former Prime Minister and Former President, Anerood Jugnauth. The reasons for the spectacular defeat of the MLP-MMM coalition is beyond the scope of this article but can be attributed to a combination of factors. These include an uninterrupted nine years in power for Ramgoolam (2005-2014), a serious of high profile scandals, the non-functioning of the Legislative Assembly for several months in 2014, and a rushed proposal around a Second Republic.

For the first time, new and social media were used by all the political parties - mainstream, small, as well as newcomers. This is not surprising as Mauritius boasts an important digital footprint with some 1.65 million mobile phones, 800,000 Internet users and 630,000 Facebook users (Internet World Statistics 2017) in a population of 1.3 million. 
Despite this digital dividend there does not seem to be a strategic approach to social media and new technology by Mauritian political parties, as there is in India, Nigeria or Ghana. In most cases what could be observed was that traditional political messages such a political leaders' addresses, public meetings and other political slogans were being posted. What was clearly absent was a strategy to engage social media users around critical and crucial ideas. However, what can be viewed as a master stroke was a video production made by Alliance Lepep entitled 'Vire Mam.. 'Vire Mam' was short video that juxtaposed the leaders of MLP and MMM, Navin Ramgoolam and Paul Berenger, vowing over the past few years never to enter into political deal. This short clip was viewed more than 500,000 times. This is quite consequential for a population of 1.3 million of which 937,000 were registered voters (Electoral Commission Office 2015).

\section{WHAT THE DATA SHOWS}

A content analysis of the Facebook pages and Youtube channels of a selected set of mainstream and small political parties covered one month of campaign prior to the day of the general election, 10 December 2014. Facebook and Youtube were selected as the two social media platforms due to their popularity among Mauritian users (see Alexa 2017).

The selected political parties were as follows: the two contending coalition parties, MLP and MMM, and another led by Anerood Jugnauth popularly known as Alliance Lepep. Three small parties were also included in the sample; Rezistans ek Alternativ, Lalit and Ensam Nu Kapav. It was also judged wise to include the Facebook pages of the different political leaders of the two coalition parties. This reflects a worldwide trend of political leaders existing and growing beyond the established boundaries of their parties.

\section{KEY OBSERVATIONS}

With the exception of the Lalit party all political parties included in the sample created their Facebook and Youtube presence in 2014. They became active with the official announcement of the date of the general election. The use of social media as a tool of communication was most visible among the opposition parties, that is Alliance Lepep and the smaller political parties. This can be explained by the fact that the incumbent's abuse of the state broadcaster, the MBC, caused opposition parties to resort to other forms of communication. As for the smaller parties, social media is a freely accessible and cheap form of communication.

2 In Creole this means turn-around people. 


\section{Type of Content - Old Wine in New Bottles}

Content is king, as the saying goes. Most of the content assessed during the onemonth time frame was what can be termed traditional fare, that is invitations to attend public meetings, clips and extracts of the speeches of different political leaders, reposting of existing interviews, and other content produced by traditional media. There was very little content produced specifically for social media with the exception of the small political party Lalit. They had produced a series of short videos prior to the general election, on a number of issues such as the role of the judiciary, the dangers of a second republic, and the impact of big money on elections. It was indeed disappointing to see the absence of any engagement between the political parties and their leaders with users of social media. This was in fact a one-way communication, merely posting traditional political messages.

Another noticeable trend was the tone of the content. There was a negative tone in most of the content analysed, with an occasional exception among the smaller parties. This was most visible in the content posted on the Facebook page of Alliance Lepep. Their main objective was to discredit the Ramgoolam/Berenger duo, highlight the numerous inconsistencies in their ideas and demonstrate how unholy their relationship was.

\section{Self Promotion: Vote for Me and my Party}

An election is an important moment is the lives of voters. It is not only about the right to vote but also about the ability to engage in a meaningful discussion on what type of society one wishes to live in. In Mauritius elections are held regularly every five years and voters' turnout has been relatively high, hovering at between $70-85 \%$ for the last ten general elections. However, the question which should be asked is the manner in which political parties and their respective leaders interact and engage with voters.

Like most of the previous elections, the 2014 general election had very little constructive exchange of ideas. For example, all political parties prepare and publicise their election manifestos. In principle, this is deemed an important document that maps out the vision of political parties for the next five years and by its very nature should be an engaging exercise. It would no doubt have been a worthwhile exercise to engage social media users, and by extension voters, around a genuine politics of ideas using their electoral manifestos.

Social media was used mainly by the parties to promote themselves and their candidates. Marketing political events was the other recurrent trend. For the mainstream coalition parties' pages and the profiles and pages of the different leaders of the two coalition parties, their events marketing concerned 
only meetings and congresses. However, the small parties had different contents promoting their door-to-door activities or the media interventions in which they participated. Besides marketing political events, another visible trend was that of marketing political leaders. For certain parties and coalitions, it was clear that their posts were promoting their leaders as the main protagonists. This led to a very leader-centric campaign in terms of which the focus was on the person rather than on the policies the party had to propose.

\section{Quality of Comments}

Feedback is an essential feature of all part of communication. A fair portion of the literature refers to the ability of new technology and social media to create a 'new republic of ideas' (Hind 2012) or a 'free public space of the internet' (Castells 2013, p. 15). The notion of e-democracies was supposed to herald a new form of e-advocacy and e-activism. However, the results have not always been conclusive as the type and quality of engagement varies according to country context.

In the case of the Mauritian general election in 2014 most of the Facebook posts and YouTube videos consisted of petty, shallow, and at times derogatory comments largely directed at leaders of specific parties. Another trend was a high level of passivity within the comments. In fact, the respondent only expressed whether he or she liked the post, or agreed with it. Very often only a thumbsup emoticon was used to express this sentiment. Other comments dealt with the certainty of winning by parties and/or coalitions. Just like the absence of constructive content previously mentioned, most of these comments were not constructive.

\section{Absence of Social Media Strategy}

Unlike elections in the other countries referred to, the 2014 Mauritian general election did not have a planned social media strategy. Social media was used on an ad hoc and random manner and most political parties and leaders felt that they could simply ride on the popularity of such platforms. As mentioned earlier, content was not specifically devised for social media interaction and engagement, but on the contrary the traditional fare was just repackaged and posted.

Facebook and to a lesser extent Youtube were the only two social platforms used, and though Twitter is a popular platform for political engagement it was ignored. This can to a certain extent be explained by the relatively low level of following at around 4\% (StatCounter, 2017). In other countries Ghana (\#ghanadecides), Nigeria (\#nigeriavotes) and more recently in Kenya (\#kenyaelections) - popular hashtags were generated by political parties, political 
leaders, and civil society groups to whip up interest and engagement among citizens. In the case of Mauritius, none of the political leaders from the mainstream political parties even have a Twitter account.

Another issue worth flagging is the non-digital presence of the Mauritian Electoral Commission Office. Unlike other Electoral Management Bodies (EMBs) across Africa, the Mauritian EMB has a very timid digital footprint with a very basic website that is essentially informative by nature. In a number of African countries, namely Kenya, Ghana, Malawi and Zimbabwe, EMBs have associated themselves with the GotToVote initiative (https://gottovote.cc) to ensure that voter registration, polling and counting are done in an interactive and engaged manner. It is quite surprising to note that despite the existing digital dividend that Mauritius possesses this has not been better exploited to create a politically engaged and interactive citizenry.

\section{THE STATUS OF SOCIAL MEDIA AND POLITICAL ENGAGEMENT AFTER THE 2014 GENERAL ELECTION}

The ruling party Alliance Lepep is currently at mid-mandate and has already lost one of its partners, the Parti Mauricien Socialiste Democrate (PMSD) whose leader, Xavier Luc Duval, was the Deputy Prime Minister and second in cabinet hierarchy. Another notable feature is that Sir Anerood Jugnauth stepped down as Prime Minister at the end of January 2017 and handed over power to his son Pravind Jugnauth. This new political landscape was coupled with a difficult economic conjuncture and a number social problems, such as the alarming spread of drugs within the country and the rise in poverty. These are challenging the governance structure of the island. Moreover this state of affairs has triggered the demand for political renewal and the need for ethical political leadership among certain segments of civil society. A number of these initiatives have used the presence of social media, particularly Facebook, to generate a community of followers. The most visible of these are as follows: Nou Republik (New Republic), Ennsellepep (One Nation), Mauritius Society Renewal, and Young Thinkers Mauritius. A quick overview of these different entities is that they wish to promote an intelligent and constructive debate' with citizens and especially with the younger generation. At the moment it is still too early to predict their impact as they are all relatively new to social media.

What about the traditional mainstream parties? Has it been business as usual? Facebook continues to remain their most used and preferred social media platform, possibly because it is the most popular, or because it is a lowmaintenance platform allowing for posting traditional fare. One noticeable feature is that the digital presence of all the mainstream political parties has increased 
considerably following the 2014 general election. However, upon closer scrutiny the quality of engagement has not really improved as Facebook remains essentially a platform for posting their conventional party messages, such as what the leader has to say, door-to-door canvassing, and press conferences. However, it is worth mentioning the case of Roshi Badhain, who used to be a minister in the Alliance Lepep government and resigned shortly after Pravind Jugnauth was passed the prime minister's baton by his father. He contends that his main grievance is the father-son deal which was never endorsed by popular mandate. Badhain created a new political party with the tagline 'be the change you want to see in Mauritius'. His main recruitment strategy is through Facebook and he is currently the political leader with the highest number of online followers. Although Badhain uses conventional posting mechanisms, he differs from the other political leaders by his relative youth and the way in which he uses his Facebook page to voice his own opinion, clarify certain information, and even share snippets of his personal life which make him likeable and contribute to his popularity.

Table 3 provides an overview of the key political parties and their respective political leaders Facebook footprint.

Table 3

Facebook Footprint: Political Party and Leader

\begin{tabular}{|l|l|}
\hline Political Party & Political Leader \\
\hline MSM & Pravind Jugnauth \\
\hline Refo000 followers & 36,000 followers \\
54,000 followers & Roshi Badhain \\
\hline Mauritius Labour Party & 135,0000 followers \\
\hline 31,000 & Navin Ramgoolam \\
\hline PMSD & 45,000 \\
\hline 28,000 & Xavier Luc Duval \\
\hline MMM & 57,000 \\
\hline 15,000 & Paul Berenger \\
\hline
\end{tabular}

\section{CONCLUSION}

This discussion on social media, elections and political engagement is important for the future of Mauritian democracy and the manner in which politics will be dispensed in the future. Mauritius will celebrate 50 years of independence in 2018, a period which has witnessed a number of democratic deficits namely the 
rise of ethno-politics, constant pre-electoral alliances and coalitions, the advent of dynastic politics, a class of ailing political leaders and the influence of big money in politics (Kasenally 2011). There seems to be an increasingly audible call for change, renewal, and new political blood, mostly on social media platforms such as Facebook. In fact, the impact so far of social media and more specifically Facebook is that political parties and their leaders want a slice of this medium of communication - they know it is popular especially among the young and by associating this provides them with a sense of modernity and connectivity. Unfortunately, the content analysis conducted during 2014 general election indicated that most of them used a conventional and non-engaging method of communication, the old wine in new bottle approach.

Therefore to ensure a more constructive approach to using social media for political engagement, and in the process crafting a new political discourse, the following might be relevant:

- Political parties must engage in a serious and structured social media strategy. It will not be meaningful nor generate quality political dialogue and engagement if they continue to use only traditional content. It might also be wise to start using other social media platforms such as Twitter. Case examples in other countries might provide some good examples.

- There is a dire need for investing in political literacy for citizens. The Mauritian citizen votes but does not know why he or she does so. A politically literate voter will trigger a change in political culture in which the business-as-usual approach will no longer be tolerated.

- Greater synergy between traditional and new media. The aim is to ensure that content and exchange is quality driven and instead of mudslinging, character assassination, and cheap politics will consist of a genuine and constructive community of ideas. Here it is important that the media, both traditional and new, up the ante and improve the quality of political discourse.

- Elections and its outcomes concern EMBs. EMBs in a number of African countries are now part of the new media and technology ecosystem. It is imperative that the Mauritian EMB be part of the conversation around social media and also that it continues to engage with citizens voters, not only during elections but also between elections. 


\section{- REFERENCES}

Ali, I 2014, 'Social Media Played Big Role in India's Election'. Available at: http:// www.voanews.com/a/social-media-emerges-as-a-key-tool-in-indiaselection/1931238.html

Aduloju, AA 2016, 'Youth Networks on Facebook and Twitter during the 2015 General Elections in Nigeria', Journal of African Elections, Special Issue Nigeria General Elections: From Reforms to Transformation.

African Union 2014, AU Election Observation Report, Mauritius, Port Louis.

Aronson, ED 2012, 'Cyber-Politics: How New Media has Revolutionized Electoral Politics in the United States', Colgate Academic Review, vol.9, no.7. Available at: http://commons.colgate.edu/car/volg/iss1/7

Bartlett, J, Krasodomski-Jones, A, Gondyi, ND, Fisher, A \& Jesperson, S 2015, Social Media for Election Communication and Monitoring in Nigeria, Demos, London.

Biswas, A, Ingle, N \& Roy, M 2014, 'Influence of Social Media on Voting Behavior', Journal of Power, Politics \& Governance, June, vol. 2.

Blumler, J, \& Katz, E 1974, The Uses of Mass Communications, Sage Publications, Beverly Hills, CA.

Bryant, J \& Thompson, S 2002, Fundamentals of Media Effects, McGraw-Hill, Boston.

Bunwaree, S \& Kasenally, R 2005, Political Parties and Democracy in Mauritius, EISA Research Report No 19.

Carlisle, JE \& Patton, RC 2013, 'Is Social Media Changing How We Understand Political Engagement? An Analysis of Facebook and the 2008 Presidential Election', Political research quarterly, vol. 66, no. 4.

Castells, M 2013, Networks of Outrage and Hope: Social Movements in the Internet Age, Polity Press, Cambridge.

Chadha, K \& Guha, P 2016, 'The Bharatiya Janata Party's Online Campaign and Citizen Involvement in India's 2014 Election', International Journal of Communication, vol. 10.

Chao, R 2014, 'How Much Influence Did Social Media Have On India's Election?'. Available at: $h t t p: / / t e c h p r e s i d e n t . c o m / n e w s / w e g o v / 25062 / I n d i a-e l e c t i o n-s o c i a l-$ media-influence.

Economist Intelligence Unit Report 2016, Democracy Index, EIU Publications, London.

Eddings, J 2015, How Social Media 'Decided, Dominated and Directed' the Nigerian Elections. Available at: http://mediashift.org/2015/04/how-social-media-decideddominated-and-directed-the-nigerian-elections/

Egbunike, N 2015, The Untold Story of Social Media and the 2015 Nigerian Elections. Available at: http://www.waryapost.com/the-untold-story-of-social-mediaand-the-2015-nigerian-elections/

EISA 2010, 'Mauritius National Assembly Elections 3 May 2010', EISA Election Observer Mission Report, no. 33. 
Freedom House Report 2016, Freedom in the World, Freedom House, [Washington, $\mathrm{DC}]$.

Hairsine, K 2016, Using social media for good during Ghana's elections, Available at: http:// www.dw.com/en/using-social-media-for-good-during-ghanas-elections/a-36646065 Herman, E \& Chomsky, N 1988, Manufacturing Consent, Pantheon Books, New York. Hind, D 2012, The Return of the Public, Verso, [London].

Hwang, AS 2016, Social Media and the Future of U.S. Presidential Campaigning, CMC Senior Theses. Available at: $h t t p: / / s c h o l a r s h i p . c l a r e m o n t . e d u / c m c \_t h e s e s / 1231$

India 2014, General elections 2014: schedule of elections General Elections to Lok Sabha and State Legislative Assemblies of Andhra Pradesh, Odisha and Sikkim, Government of India Press, New Delhi. Available at: http://eci.nic.in/eci_main1/current/Press\%20 Note\%20GE-2014_05032014.pdf

Internet and Mobile Association of India 2015, Report on Social Media in India - 2013. Available at: http://www.iamai.in/sites/default/files/annual_report/ AnnualReport2014-15.pdf

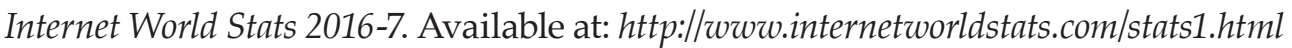
Internet World Statistics 2017 - http://www.internetworldstats.com/africa.htm\#mu Kasenally, R 2009, 'Mauritius' in D Kadima \& S Booysen (eds.) Compendium of Elections in Southern Africa 1989-2009: 20 Years of Multiparty Democracy, EISA, Johannesburg.

Kasenally, R 2011, 'Mauritius: Paradise Reconsidered', Journal of Democracy, vol. 22, no. 2.

Kavanagh, D 1995, Elections Campaigning: The New Marketing of Politics, Wiley. Hoboken, NJ.

Klapper, J 1960, The Effects of Mass Communications, Free Press, New York.

Kushin, MJ \& Yamamoto, M 2010, Did Social Media Really Matter? College Students' Use of Online Media and Political Decision Making in the 2008 Election, Association for Education in Journalism and Mass Communication, Columbia, SC.

Lasswell, D 1927, 'The Theory of Political Propaganda', The American Political Science Review, vol. 21, no. 3.

Lazarsfeld, PF, Berelson, B \& Gaudet, H 1944, The people's choice: How the voter makes up his mind in a presidential campaign, Columbia University Press, New York. Lippmann, W 1922, Public Opinion, Harcourt Brace, New York.

Leshchenko, S 2014, The Maidan and Beyond: The Media's Role, Johns Hopkins University Press, Baltimore, MD.

Mauritius 2002, IBA Act, [Port Louis, Mauritius]

Mauritius 1838, Criminal Code, [Port Louis, Mauritius]

Mauritius, 1982, MBC Act, [Port Louis, Mauritius]

Mauritius 1972, Official Secrets Act, [Port Louis, Mauritius]

Mauritius 1991, Public Gathering Act, [Port Louis, Mauritius] 
Miller, C 2008, How Obama's Internet Campaign Changed Politics. Available at: https:// bits.blogs.nytimes.com/2008/11/07/how-obamas-internet-campaign-changedpolitics/?_r=0

Nelson, D 2014, 'Magic' Modi uses hologram to address dozens of rallies at once. Available at: http://www.telegraph.co.uk/news/worldnews/asia/india/10803961/Magic-Modiuses-hologram-to-address-dozens-of-rallies-at-once.html

Olowojolu, O 2016, 'Role of Media in 2015 Presidential Election in Nigeria', International Journal of Politics and Good Governance, vol. VII.

Opara, C 2017, How Social Media Played a Role in Ghana's 2016 Elections. Available at: http://www.signalng.com/op-unedited-social-media-played-role-ghanas-2016elections-chris-oparal

Paroomal, M 2008, La presse dans l'ile Maurice post-coloniale/ mutations et continuités, in L'ile Maurice face à ses nouveaux défis, L'Harmattan, Reunion.

Penplusbytes 2016, 3rd Governance Social Media Index Report: Responsible, Transparent and Accountable Governance. Available at: www. penplusbytes.org

Penplusbytes 2016, Ghana Elections 2016: The Game Changing Role of Tech and New Media Tools. Available at: www. penplusbytes.org

Plattner, MF 2012, Media and democracy: the long view, John Hopkins University Press, Baltimore, MD.

Price, L 2015, The Modi Effect: Inside Narendra Modi's Campaign to Transform India, Quercus, London.

Rotberg, R 2003, 'The roots of Africa's leadership deficit', Compass: A Journal of Leadership, vol. 1, no. 1.September 30, pp. 28-32.

Schiffrin, A (ed.) 2017, In the search of power: media capture and the threat to democracy, CIMA Publication.

Shirky, C 2011, 'The Political Power of Social Media: Technology, the Public Sphere, and Political Change', Foreign Relations, vol. 90, no. 1, pp. 28-41.

Singh, RP 2016, 'Role of social networking sites in Indian politics', International Journal of Humanities and Social Science Research, vol. 2.

StatCounter 2017, Social Media Stats in Mauritius, August 2016-August 2017. Available at: http://gs.statcounter.com/social-media-stats/all/mauritius

Stelter, B 2008, 'The Facebooker Who Friended Obama', New York Times. Available at: http://www.nytimes.com/2008/07/07/technology/07hughes.html?pagewanted=allE_ $r=0$

Udoka, UE 2015, 'Social Media and Political Effects: A Case Study of the 2015 Nigeria's Presidential Election', International Journal of Social Science and Humanities Research, vol. 3.

Vitak, J, Zube, P, Smock, A, Carr, C, Ellison, N, \& Lampe, C 2009, "Poking" people to participate: Facebook and political participation in the 2008 election. Paper presented at the annual conference of the International Communication Association, Chicago. 
Walker, C \& Orttung, RW 2014, Breaking the News: The Role of State-Run Media, Johns Hopkins University Press, Baltimore, MD.

Wani, G et al. 2014, 'A Survey on Impact of Social Media on Election System', International Journal of Computer Science and Information Technologies, vol. 5, no. 6 .

Whitten, S 2015, Can 140 characters affect the 2016 presidential election. Available at: http://www.cnbc.com/2015/11/05/can-140-characters-affect-the-2016-presidentialelection.html 